\title{
ANALISIS PENGARUH TEBAL PLAT TERHADAP KARAKTERISTIK MEKANIK PEGAS DAUN PADA PROTOTIPE MOBIL FISH CAR UNEJ (FCU) MUDSKIP
}

\author{
ANALYSIS OF THE EFFECT OF PLATE THICHNESS ONMECHANICAL \\ CHARACTERISTIC OF LEAF SPRING ON THE FISH CAR UNEJ (FCU) \\ MUDSKIP PROTOTYPE
}

\author{
${ }^{1}$ Khoirur Rohman, Rika Dwi Hidayatul Qoryah ${ }^{2 *}$, \\ Aris Zainul Muttaqin ${ }^{3}$, dan Santoso Mulyadi ${ }^{4}$ \\ Jurusan Teknik Mesin, Fakultas Teknik, Universitas Jember
}

Submitted:29-12-2020; Revised: 01-03-2021; Accepted: 15-06-2021

\begin{abstract}
Fish Car Unej (FCU) Mudskip is a car designed with a rural terrain system, especially for fishing transportation. FCU Mudskip uses leaf spring suspension at the rear to support the weight of the vehicle, that is leaning towards the rear. The load of the vehicle is inclined to the rear due to the car carrying system in the form of fish and water. This conveying system can cause leaf spring failure. Therefore, this study aims to determine the value of stress, strain and cycle on leaf springs. Ansys 18.1 software was used to obtain stress, strain, and leaf spring cycle values with a thickness of $7 \mathrm{~mm}, 10 \mathrm{~mm}$, and $13 \mathrm{~mm}$. The value of stress on leaf springs with thickness 7 is 124,31 $x$ $10^{6} \mathrm{~N} / \mathrm{m}^{2}$; thickness $10 \mathrm{~mm}$ is $74,92 \times 10^{6} \mathrm{~N} / \mathrm{m}^{2}$; thickness $13 \mathrm{~mm}$ is $48,08 \times 10^{6} \mathrm{~N} / \mathrm{m}^{2}$; the value of strain on leaf springs with a thickness of $7 \mathrm{~mm}$ is 0,00075; a thickness of $10 \mathrm{~mm}$ is 0,00045; a thickness of $13 \mathrm{~mm}$ is 0,00029; Acceptable cycles of leaf springs are $7 \mathrm{~mm}$ thick is 69206 cycles, $10 \mathrm{~mm}$ is 77833 cycles, and $13 \mathrm{~mm}$ thick is 93054 cycles. Leaf springs with a thickness of $13 \mathrm{~mm}$ are the most optimal leaf springs because they can receive the most cycles of 93054 cycles, according to the function of leaf springs as vibration dampers.
\end{abstract}

Keywords: Cycle; Leaf spring; Stress; Strain.

\begin{abstract}
ABSTRAK
Fish Car Unej (FCU) Mudskip merupakan mobil yang didesain dengan sistem medan pedesaan, khususnya untuk pengangkutan perikanan. Mobil FCU Mudskip menggunakan suspensi pegas daun pada bagian belakang, berfungsi menahan beban kendaraan yang condong ke bagian belakang. Beban kendaraan condong ke bagian belakang disebabkan oleh sistem pengangkutan mobil berupa ikan dan air. Sistem pengangkutan tersebut dapat menyebabkan kegagalan pada bagian pegas daun. Oleh karena itu, penelitian ini bertujuan mengetahui nilai tegangan, regangan dan siklus pada pegas daun. Software Ansys 18.1 digunakan untuk mendapatkan nilai tegangan, regangan, dan siklus pegas daun dengan tebal $7 \mathrm{~mm}, 10 \mathrm{~mm}$, dan $13 \mathrm{~mm}$. Nilai tegangan pada pegas daun tebal 7 adalah sebesar $124,31 \times 10^{6} \mathrm{~N} /$ $\mathrm{m}^{2}$; tebal $10 \mathrm{~mm}$ adalah sebesar 74,92 x $10^{6} \mathrm{~N} / \mathrm{m}^{2}$; tebal $13 \mathrm{~mm}$ adalah sebesar 48,08 x 106 N/m²; nilai regangan pada pegas daun tebal $7 \mathrm{~mm}$ adalah sebesar 0,00075; tebal $10 \mathrm{~mm}$ adalah sebesar 0,00045; tebal
\end{abstract}

*Corresponding author: rika.teknik@unej.ac.id

Copyright $\odot 2021$ THE AUTHOR(S).This article is distributed under a Creative Commons Attribution-Share Alike 4.0 International license. Jurnal Teknosains is published by the Graduate School of Universitas Gadjah Mada. 
$13 \mathrm{~mm}$ adalah sebesar 0,00029; siklus yang dapat diterima pegas daun tebal $7 \mathrm{~mm}$ adalah sebesar 69206 siklus, $10 \mathrm{~mm}$ adalah sebesar 77833 siklus, dan tebal $13 \mathrm{~mm}$ adalah sebesar 93054 siklus. Pegas daun tebal $13 \mathrm{~mm}$ merupakan pegas daun yang paling lama umur pakainya karena dapat menerima siklus terbanyak yaitu 93054 siklus, sesuai fungsi dari pegas daun sebagai peredam getaran.

Kata Kunci:Pegas daun;Regangan; Siklus;Tegangan.

\section{PENGANTAR}

Fish Car Unej (FCU) Mudskip adalah mobil yang didesain dengan sistem medan pedesaan, khususnya untuk pengangkutan perikanan (gambar 1). FCU Mudskip menggunakan sistem transmisi manual dan beroperasi
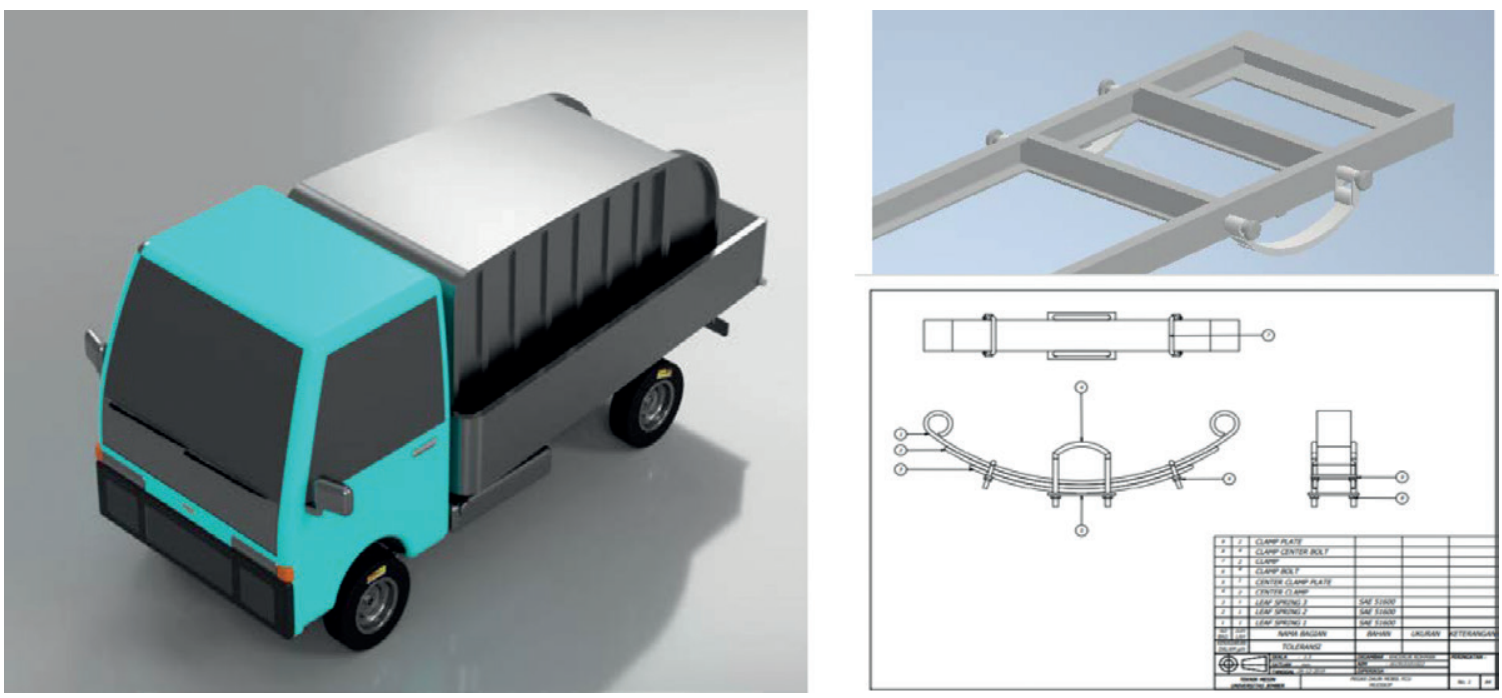

menggunakan mesin bagian depan dengan penggerak roda belakang. Suspensi kendaraan ini menggunakan pegas ulir untuk bagian depan dan pegas daun untuk bagian belakang. FCU Mudskip menggunakan sasis tipe ladder (tangga) yang banyak digunakan pada kendaraan pengangkut (Yoga $d k k ., 2018)$.

Suspensi mobil menggunakan pegas daun berfungsi menahan beban kendaraan, yang terdiri dari beberapa plat datar yang disatukan=menggunakan clamp. Pegas daun berfungsi0sebagai peredam getaran dan sebagai=penopang rangka kendaran. Pegas daun dapat mengalami kegagalan akibat menopang bobot kendaraan dan menerima beban secara berulang (Thamrin, 2009).

Gambar 1

Prototipe Mobil Fish Car Unej (FCU) Mudskip

Sumber: Olah data penulis

Sepitra dan Rizal (2013) meneliti tentang kegagalan pegas daun pada truk colt=diesel. Pegas daun truk colt=diesel mengalami perpatahan pada susunan=pertama. Posisi patahan pegas daun terjadi pada bagian tengah, merupakan=bagian penerima beban terbesar dan terdapat lubang kecil pada bagian tersebut sebagai tempat baut pengikat pegas. Penyebab=utama kegagalan pegas adalah terjadinya korosi-setempat/pitting pada pegas daun. Korosi tersebut mengasilkan takikan yang mengakibatkan adanya kosentrasi=tegangan. Beban berulang serta kondisi korosi yang terus berlangsung menyebabkan kelelahan pada pegas hingga terjadinya patah (Sepitra dan Rizal, 2013).

Stanco (2018) meneliti tantang stress analysis pada leaf spring menggunakan metode eksperimental dan perhitungan numerik. Penelitian tersebut dilakukan untuk mengetahui penyebab terjadinya retak pada pegas daun. Kegagalan pada pegas daun disebabkan karena pegas daun mengalami kelebihan beban, dalam kondisi tersebut diperlukan proses desain ulang pada pegas daun agar pegas dapat menahan beban muatan kendaraan (Stanco, 2018). 


\section{KHOIRUR ROHMAN, RIKA DWI HIDAYATUL QORYAH, ARIS ZAINUL MUTTAQIN, DAN SANTOSO MULYADI \& ANALISIS PENGARUH TEBAL PLAT TERHADAP ...}

Fimansyah (2015) melakukan analisis tentang suspensi pegas daun menggunakan metode elemen hingga. Analisis dilakukan pada seluruh lempengan pegas menggunakan simulasi perangkat lunak Solidwork, dari penelitian tersebut diperoleh hasil bahwa perbedaan=dimensi pegas daun akan menghasilkan nilai tegangan yang berbeda, tegangan maksimum terjadi pada master leaf dengan panjang=1300 $\mathrm{mm}$, tebal $12 \mathrm{~mm}$ dan lebar=70 mm (Firmansyah, 2015).

Lukman (2018) melakukan-analisis desain dan optimasi-pegas daun pada kendaraan roda tiga menggunakan=perangkat lunak Catia v5. Modifikasi dilakukan pada pegas daun dengan dimensi=sama. Modifikasi berupa penambahan slot pada=penampang pegas yaitu 1 slot, 2 slot dan 3 slot. Dari hasil analisis tersebut dapat=disimpulkan bahwa pegas daun=original (tanpa modifikasi) merupakan pegas daun yang paling optimal karena tegangan yang dihasilkan memiliki nilai=terkecil (Lukman, 2018).

Meijaard (2015) meneliti pengaruh ketidaksempurnaan bentuk pegas daun terhadap kinerjanya. Dari penelitihan tersebut diketahui bahwa ketidak sempurnaan bentuk pegas daun dapat mempengaruhi kekakuan dari pegas daun. Urutan pemasangan pegas daun merupakan faktor utama yang mempengaruhi kekakuan pegas daun. Pegas daun utama harus memiliki dimensi lebih panjang dan seterusnya mengecil ke bawah untuk menambah nilai kekakuan dari pegas daun (Meijaard, 2015).

Bandarkar dan Shekhawat (2014) mengembangkan metodologi dalam merancang suspensi pegas daun. Terdapat beberapa metodologi dalam merancang pegas daun. Metode elemen hingga dipilih karena dapat menyelesaikan analisis pada pegas daun berupa ketahanan, penanganan, kenyamanan berkendara, uji optimalisasi final dengan waktu singkat (Bandarkar dan Shekhawat, 2014).

Berdasarkan studi literatur di atas, penelitian ini bertujuan untuk mengetahui pengaruh tebal pegas daun terhadap karakteristik mekanik pada pegas daun (nilai tegangan, regangan dan siklus). Sehingga dapat memprediksi umur dari pegas daun tersebut yang berfungsi sebagai peredam getaran.

\section{METODE \\ Material Pegas Daun}

Material pegas merupakan material SAE 5160. Material tersebut merupakan material yang digunakan pada pegas daun sesuai dengan standar SAE (Society of Automotive Engineer). AZoM (2012), menuliskan datasheet dari material SAE 5160 dan dapat dilihat pada tabel 1, 2, 3 dan 4 di bawah ini.

Tabel 1

Komposis Kimia

\begin{tabular}{ll}
\hline \multicolumn{1}{c}{ Unsur } & \multicolumn{1}{c}{ Kandungan (\%) } \\
\hline Iron $(\mathrm{Fe})$ & $97,085-97,84$ \\
\hline Mangan $(\mathrm{Mn})$ & $0,750-1$ \\
\hline Krom $(\mathrm{Cr})$ & $0,7-0,9$ \\
\hline Karbon $(\mathrm{C})$ & $0,560-0,640$ \\
\hline Posfor $(\mathrm{P})$ & $\leq 0,0350$ \\
\hline Silikon $(\mathrm{Si})$ & $0,150-0,3$ \\
\hline Sulfur $(\mathrm{S})$ & $\leq 0,04$ \\
\hline
\end{tabular}

Tabel 2

Sifat Fisika

\begin{tabular}{lc}
\hline \multicolumn{1}{c}{ Komposisi Fisika } & \multicolumn{1}{c}{ Nilai } \\
\hline Densitas & $7,85 \mathrm{~g} / \mathrm{cm}^{3}$ \\
\hline
\end{tabular}

Tabel 3

Sifat Mekanik

\begin{tabular}{ll}
\hline \multicolumn{1}{c}{ Sifat Mekanik } & \multicolumn{1}{c}{ Nilai } \\
\hline Ultimate Tensile Strength & $724 \times 10^{6} \mathrm{~N} / \mathrm{m}^{2}$ \\
\hline Yield Tensile Strenght & $275 \times 10^{6} \mathrm{~N} / \mathrm{m}^{2}$ \\
\hline Modulus Of Elasticity & $190-210 \times 10^{9} \mathrm{~N} / \mathrm{m}^{2}$ \\
\hline Bulk Modulus & $140 \times 10^{9} \mathrm{~N} / \mathrm{m}^{2}$ \\
\hline Shear Modulus & $80 \times 10^{9} \mathrm{~N} / \mathrm{m}^{2}$ \\
\hline Poissons Ratio & $0,27-0,30$ \\
\hline Elongation At Break & $17,20 \%$ \\
\hline Brinell Hardness & 197 \\
\hline Vikers Hardness & 207 \\
\hline Machinability & 55 \\
\hline
\end{tabular}

Tabel 4

Sifat Termal

\begin{tabular}{cc}
\hline Sifat Termal & \multicolumn{1}{c}{ Nilai } \\
\hline Konduktifitas Termal & $46,6 \mathrm{~W} / \mathrm{mK}$ \\
\hline
\end{tabular}




\section{Desain Pegas Daun}

Desain pegas daun yang digunakan dalam penelitian merupakan desain dengan dimensi panjang dan lebar yang sama. perbedaan hanya pada tebal setiap plat pada pegas daun. Variasi tebal pegas daun yaitu $7 \mathrm{~mm}$ (gambar 2a), 10 $\mathrm{mm}$ (gambar 2b) dan $13 \mathrm{~mm}$ (gambar 3c).

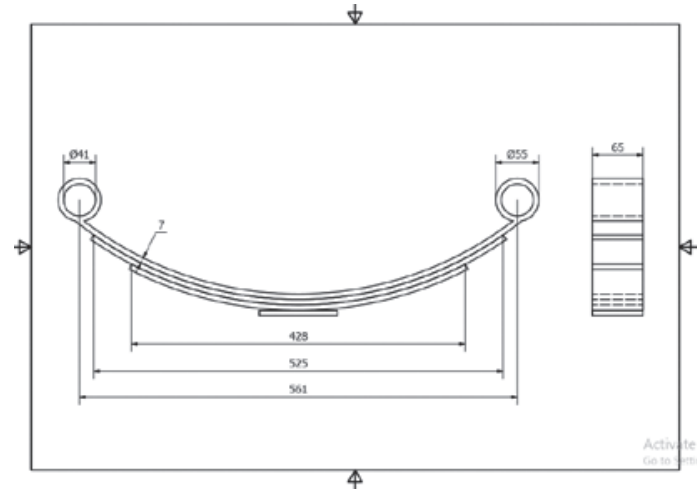

(a)

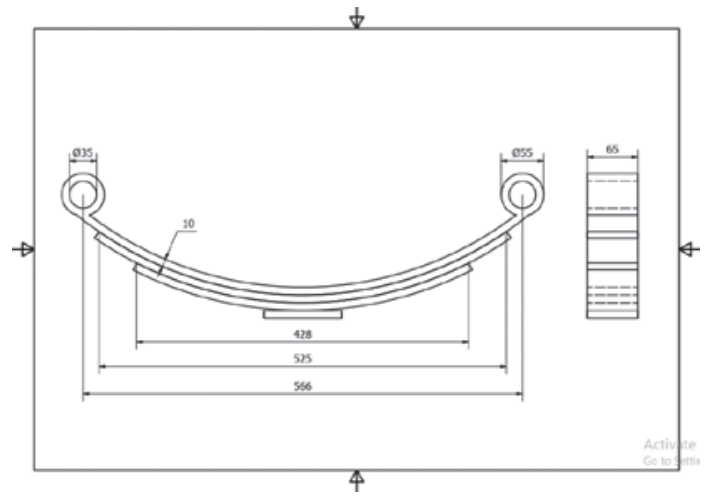

(b)

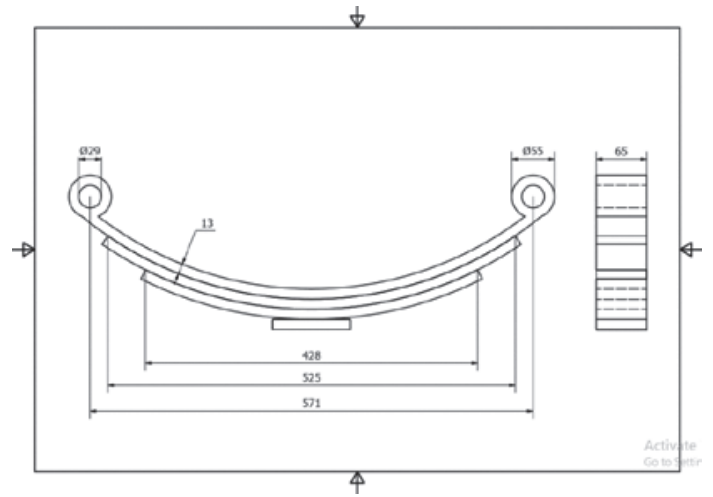

(c)

Gambar 2

Tebal Pegas Daun: (a) $7 \mathrm{~mm}$, (b) $10 \mathrm{~mm}$,

(c) $13 \mathrm{~mm}$

\section{Beban Pada Pegas Daun}

Beban yang digunakan pada simulasi pegas daun dihitung dengan metode kesetimbangan gaya. Gaya yang bekerja pada pegas merupakan beban radial berupa berat kendaraan $700 \mathrm{~kg}$, berat muatan maksimum 750 $\mathrm{kg}$ dan berat penumpang $150 \mathrm{~kg}$ menghasilkan berat total kendaraan sebesar $1600 \mathrm{~kg}$ atau 16000 N. Pemodelan dari pembebanan mobil FCU Mudskip dapat dilihat pada gambar 3 di bawah.

A merupakan roda depan (tumpuan depan) dan B merupakan roda belakang (tumpuan belakang). Persamaan 1, 2 dan 3 di bawah ini digunakan untuk menentukan beban yang diterima oleh pegas.

$\begin{aligned} \Sigma F_{y} & =0 \\ \uparrow & =\downarrow\end{aligned}$

$\mathrm{R}_{\mathrm{ay}}+\mathrm{R}_{\mathrm{by}}=\mathrm{F}$

$\mathrm{R}_{\mathrm{ay}}+\mathrm{R}_{\mathrm{by}}=16000 \mathrm{~N}$

$\Sigma \mathrm{M}_{\mathrm{A}}=0$

$G=$

$\mathrm{Rb}_{\mathrm{b}} \times(1,74+1,54)=16000 \times 1,74$

$\mathrm{R}_{\mathrm{b}} \times 3,28=27840$

$\mathrm{R}_{\mathrm{b}}=27840 / 3,28$

$\mathrm{R}_{\mathrm{b}}=8487,8 \mathrm{~N}$

$\mathrm{Rb}$ (roda belakang) $=2$ Pegas daun $8487,8=2$ pegas daun.

Pegas daun $=8487,8 / 2$

Pegas daun $=4243,9 \mathrm{~N}$

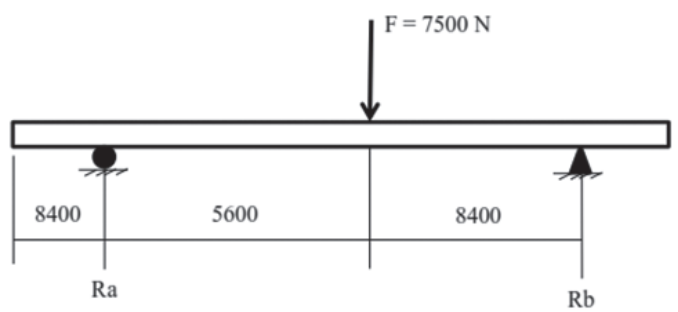

Gambar 3

Model Pembebanan Pegas Daun

Dari proses perhitungan menggunakan metode kestimbangan gaya dapat diperoleh bahwa gaya yang diterima oleh suspensi pegas daun adalah $4243,9 \mathrm{~N}$, gaya yang diperoleh 
selanjutnya akan digunakan sebagai masukan beban dalam proses simulasi.

\section{Posisi Gaya dan Tumpuan}

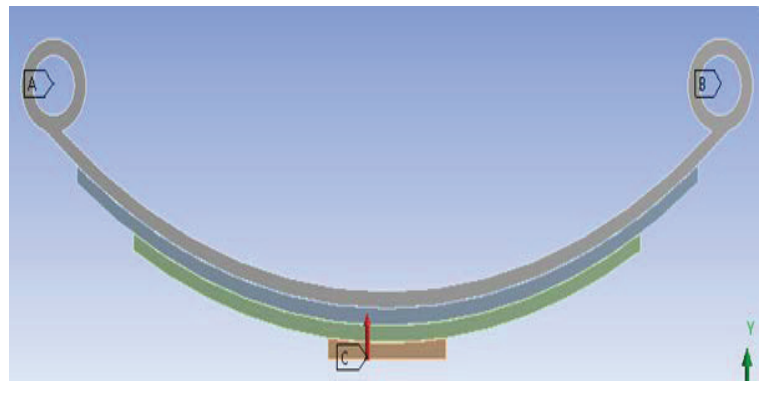

Gambar 5

Tahapan Simulasi Software Ansys 18.1

Posisi gaya dan tumpuan ditunjukkan pada gambar 5 dengan simbol A, B dan C.
Bagian A merupakan tumpuan depan dari pegas. Pada tumpuan A bagian pegas tersebut mengalami rotasi pada titik pusatnya. Pada tumpuan B merupakan tumpuan belakang dari pegas. Pada tumpuan B mengalami gerak translasi linier kearah belakang. Pada bagian $\mathrm{C}$ merupakan letak pembebanan pada pegas daun sama besar.

\section{Simulasi Ansys 18.1}

Hasil desain pegas daun yang sudah dibuat disimulasikan menggunakan Software Ansys 18.1. Tahapan simulasi dapat dilihat pada gambar 6, dimana diawali dengan proses meshing. Ukuran meshing adalah $10 \mathrm{~mm}$, dilakukan pada seluruh desain pegas daun. Hasil dari simulasi berupa tegangan, regangan, defleksi dan siklus.

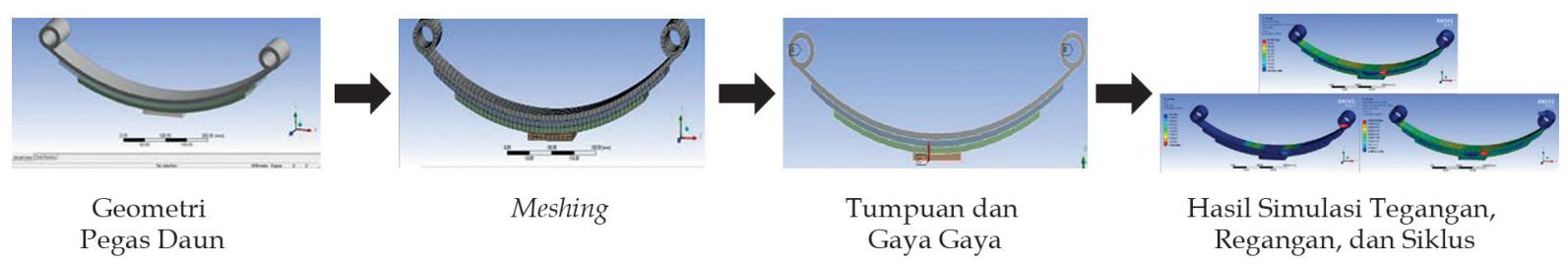

Gambar 6

Tahapan Simulasi Software Ansys 18.1

\section{Analisis Hasil}

Simulasi pegas daun mobil FCU Mudskip menghasilkan 3 komponen utama dalam menentukan karakteristik mekanik pada pegas daun, yaitu: nilai tegangan, nilai regangan, dan nilai siklus. Nilai tegangan digunakan untuk mentukan tegangan yang diterima oleh pegas daun dan dibandingkan dengan tegangan yield yang dimiliki oleh material, sesuai dengan teori Von Mises menjelaskan bahwa material tidak akan mengalami patah jika tegangan yang dihasilkan tidak melebihi tegangan yield material. Nilai regangan merupakan nilai perubahan panjang pegas daun setelah dikenai beban dibagi dengan panjang awal. Nilai besaran defleksi yang digunakan untuk menentukan perubahan bentuk setelah dikenai beban terhadap batas minimum defleksi yang sudah ditentukan yaitu 66,5 mm (Sudarsono,
2012). Nilai siklus digunakan untuk mengetahui besar siklus maksimum yang dapat diterima oleh pegas sebelum mengalami kegagalan.

\section{HASIL DAN PEMBAHASAN Hasil Tegngan Pegas Daun}

Analisis tegangan dilakukan pada setiap variasi tebal pegas daun. Dari hasil simulasi diperoleh distribusi tegangan pada masingmasing pegas yang disimbolkan dengan warna.

Gambar 7 di bawah menunjukan perbandingan tegangan yang terjadi pada setiap variasi pegas daun dengan beban 4243,9 N. Tegangan yang terjadi pada masingmasing pegas daun memiliki perbedaan nilai maksimum dan nilai minimum. Nilai tegangan maksimum dan minimum pada setiap variasi pegas daun dapat dilihat pada tabel 5 di bawah ini. 
Tabel 5

Nilai Tegangan Pegas Daun

\begin{tabular}{lll}
\hline $\begin{array}{l}\text { Tebal } \\
(\mathrm{mm})\end{array}$ & $\begin{array}{c}\text { Max. } \\
\left(10^{6} \mathrm{~N} / \mathrm{m}^{2}\right)\end{array}$ & $\begin{array}{c}\text { Min. } \\
\left(10^{6} \mathrm{~N} / \mathrm{m}^{2}\right)\end{array}$ \\
\hline 7 & 124,31 & 0,35 \\
\hline 10 & 74,92 & 0,33 \\
\hline 13 & 48,08 & 0,12 \\
\hline
\end{tabular}

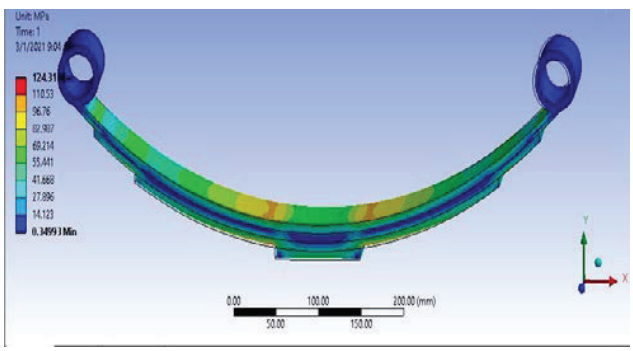

(a)

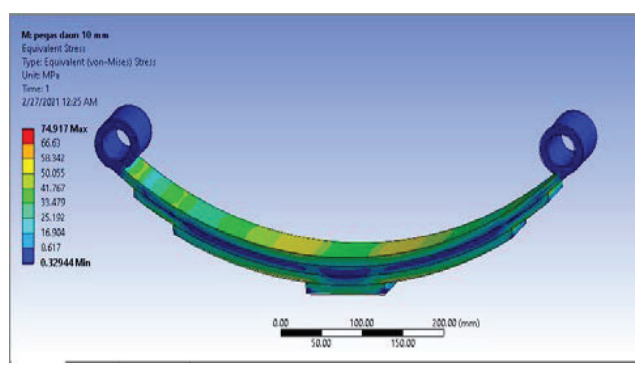

(b)

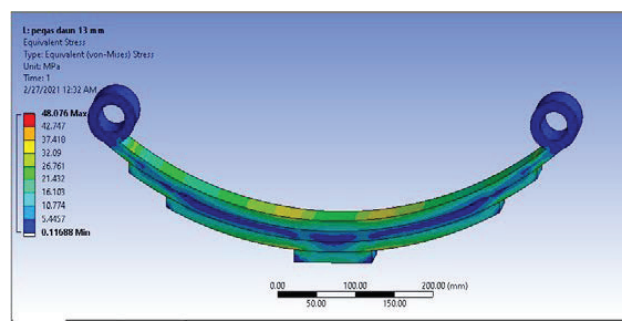

(c)

Gambar 7

Perbandingan Tegangan Pegas Daun

Pegas daun dengan tebal $7 \mathrm{~mm}$ memiliki nilai tegangan tertinggi. Sedangkan pegas daun dengan tebal $13 \mathrm{~mm}$ memiliki nilai tegangan terendah. Hasil tegangan yang terjadi sesuai dengan teori tegangan yaitu tegangan adalah gaya per satuan luas, semakin besar dimensi pegas daun maka nilai tegangan yang dihasilkan akan semakin kecil.

\section{Hasil Regangan Pegas Daun}

Hasil simulasi regangan pada pegas daun dapat dilihat pada gambar 8 . Nilai regangan terbesar terjadi pada pegas daun dengan tebal $7 \mathrm{~mm}$ sebesar 0,00075 . Nilai regangan terkecil terjadi pada pegas daun $13 \mathrm{~mm}$ sebesar 0,00029. Secara rinci, nilai regangan pegas daun dapat dilihat pada tabel 6 di bawah.

Tabel 6

Nilai Regangan Pegas Daun

\begin{tabular}{lrl}
\hline Tebal $(\mathbf{m m})$ & Max. & \multicolumn{1}{c}{ Min. } \\
\hline 7 & 0,00075 & 0,0000067 \\
\hline 10 & 0,00045 & 0,0000035 \\
\hline 13 & 0,00029 & 0,00000075 \\
\hline
\end{tabular}

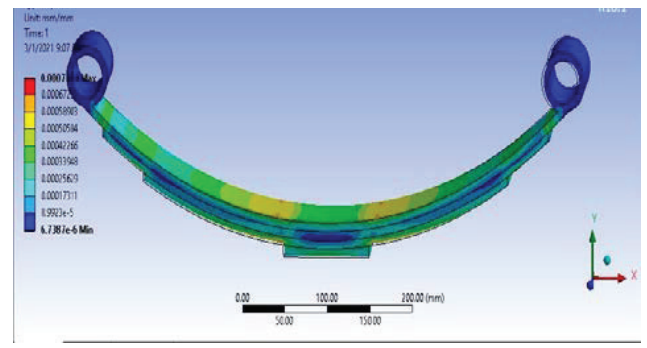

(a)

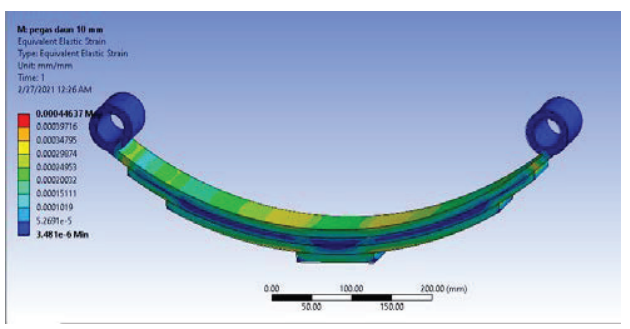

(b)

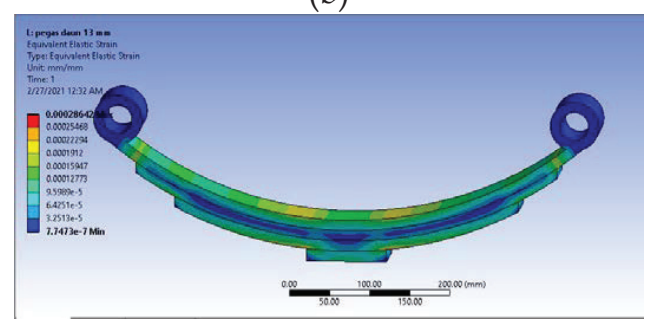

(c)

Gambar 8

Perbandingan Regangan Pegas Daun

Berdasarkan data pada tabel 6 dan gambar 8 di atas dapat diperoleh kesimpulan bahwa perbedaan tebal pegas daun memiliki pengaruh terhadap regangan yang dihasilkan. Hal ini 
sesuai dengan teori tegangan, dimana akan mempengaruhi nilai regangan yang terjadi. Semakin besar tegangan yang terjadi maka regangan yang terjadi akan semakin besar sesuai dengan teori Hook yang menyatakan bahwa tegangan dan regangan memiliki nilai proporsional sebelum melewati batas plastis.

\section{Hasil Defleksi Pegas Daun}

Nilai defleksi didapat dengan pengukuran dari permukaan awal ke posisi setelah terjadi regangan. Defleksi pada setiap variasi pegas daun menghasilkan nilai yang berbeda. Letak defleksi tertinggi dapat dilihat pada gambar 9 dan nilai defleksi setiap tebal pegas daun dapat dilihat pada tabel 7 .

Berdasarkan data tersebut defleksi dipengaruhi oleh ketebalan pegas daun, semakin tebal pegas daun maka nilai defleksi semakin rendah. Semakin rendah nilai defleksi maka nilai kekakuan pegas daun semakin tinggi. Sehingga nilai regangan dan tegangan dari pegas daun semakin kecil.

Tabel 7

Nilai Defleksi Pegas Daun

\begin{tabular}{lll}
\hline Tebal (mm) & Max. $(\mathbf{m m})$ & \multicolumn{1}{c}{ Min. $(\mathbf{m m})$} \\
\hline 7 & 1,68 & $-0,33$ \\
\hline 10 & 0,74 & $-0,17$ \\
\hline 13 & 0.36 & $-0,09$ \\
\hline
\end{tabular}

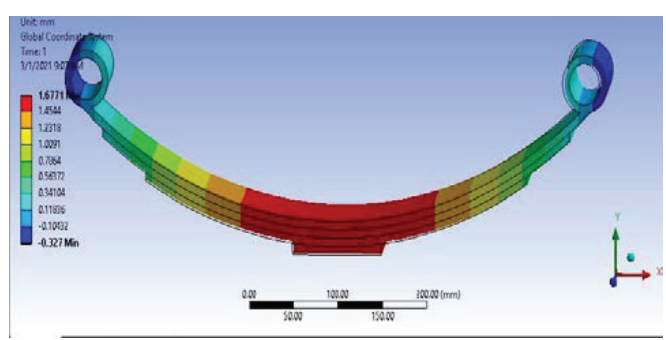

(a)

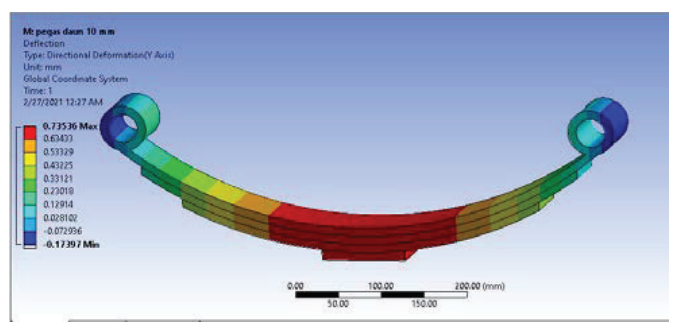

(b)

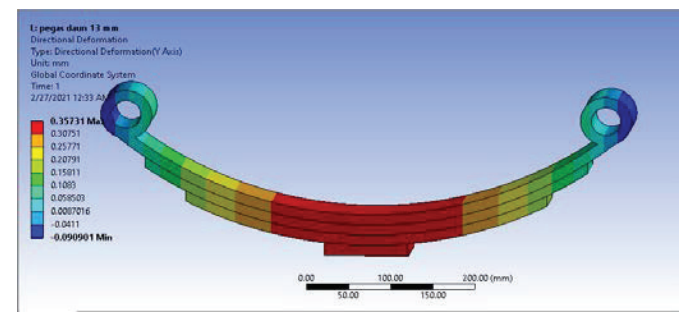

(c)

Gambar 9

Perbandingan Defleksi Pegas Daun

Hasil Life Siklus Pegas Daun

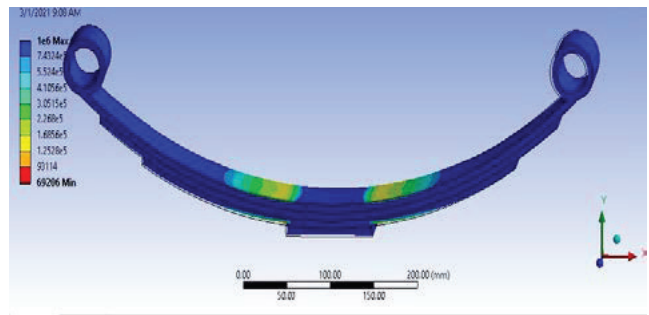

(a)

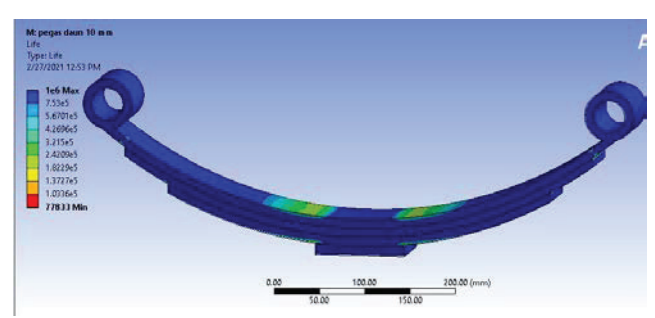

(b)

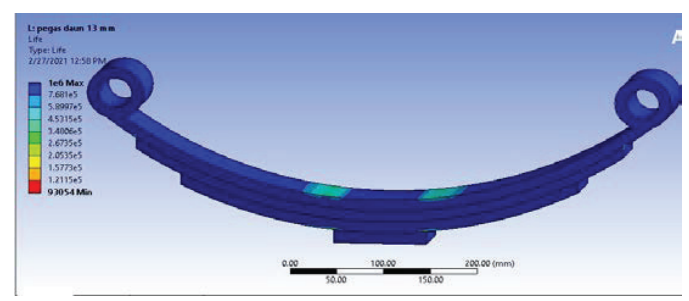

(c)

Gambar 10

Perbandingan Siklus Pegas Daun

Berdasrkan gambar 10 di atas, life siklus dapat diterima oleh setiap variasi pegas daun dengan beban 4243,9 N. Nilai life siklus yang dapat diterima setiap variasi pegas daun disajikan pada tabel 8 sebagai berikut. 
Tabel 8

Nilai Siklus Pegas Daun

\begin{tabular}{|c|c|}
\hline Tebal (mm) & Nilai Siklus (Siklus) \\
\hline 7 & 69206 \\
\hline 10 & 77833 \\
\hline 13 & 93054 \\
\hline
\end{tabular}

\section{Analisis Hasil Tegangan, Regangan dan Siklus}

Kegagalan pada material terjadi karena adanya tegangan bending yang terjadi pada pegas daun. Tegangan bending pada pegas daun menghasilkan defleksi searah sumbu Y (gambar 9). Nilai defleksi tersebut memiliki perbedaan sesuai dengan tebal pegas mobil. Defleksi yang terjadi pada pegas dapat menyebabkan kegagalan jika nilai tegangan yang terjadi pada setiap defleksi memiliki nilai tegangan lebih besar dibandingkan dengan tegangan yield dari material. Jika nilai tegangan melebihi nilai tegangan yield dari material maka defleksi yang terjadi berupa defleksi plastis. Defleksi plastis merupakan tahap awal terjadi kegagalan pada material.

Kegagalan pada material terjadi karena adanya deformasi plastis, dimana material tersebut terus menerus dikenai beban sehingga material mengalami kegagalan. Deformasi plastis terjadi ketika tegangan yang terjadi pada benda kerja melebihi tegangan luluh dari material tersebut atau yang biasa disebut dengan yield. Untuk mengetahui desain pegas daun apakah aman ketika digunakan perlu dilakukan perbandingan tegangan yang terjadi dengan tegangan luluh material.

Tabel 9

Perbandingan Tegangan dan Tegangan Yield

\begin{tabular}{llcl}
\hline $\begin{array}{c}\text { Tebal Pegas } \\
(\mathbf{m m})\end{array}$ & $\begin{array}{c}\text { Tegangan pada pegas } \\
\left(\mathbf{1 0}^{\mathbf{6}} \mathbf{N} / \mathbf{m}^{\mathbf{2}}\right)\end{array}$ & $\begin{array}{c}\text { Tegangan Yield Material SAE 5160 } \\
\left(\mathbf{1 0}^{\mathbf{6}} \mathbf{N} / \mathbf{m}^{\mathbf{2}}\right)\end{array}$ & Safety Factor \\
\hline 7 & 124,31 & 275 & 2,21 \\
\hline 10 & 74,92 & 275 & 3,67 \\
\hline 13 & 48,08 & 275 & 5,72 \\
\hline
\end{tabular}

Dari tabel 9 di atas, jika dibandingkan antara tegangan yang terjadi dengan tegangan luluh pada material, akan diperoleh nilai safety factor dari setiap variasi tebal pegas daun yang dibuat. Nilai safety factor pegas daun dengan tebal $7 \mathrm{~mm}$ adalah sebesar 2,21; pegas daun dengan tebal $10 \mathrm{~mm}$ adalah sebesar 3,67 dan pegas daun dengan tebal $13 \mathrm{~mm}$ adalah sebesar 5,72 . Berdasarkan nilai safety factor di atas, pegas daun mobil Fish Car Unej (FCU) Mudskip aman digunakan. Hal ini dikarenakan suatu perhitungan ini dikatakan aman jika nilai safety factor lebih besar dari 1,0 sampai 10 (Gere dan Timoshenko, 2000)
Untuk life siklus pegas daun dapat dilihat dari nilai tegangan yang terjadi. Semakin besar tegangan pada pegas daun maka siklus yang dapat diterima akan semakin kecil. Hal ini dapat dibuktikan dengan membandingkan antara hasil simulasi tegangan (gambar 7) dengan hasil simulasi siklus (gambar 10), sehingga didapat grafik (gambar 10.a). Berdasarkan grafik tersebut dapat dilihat bahwa peningkatan tegangan yang terjadi pada pegas daun akan menghasilkan penurunan siklus yang dapat diterima oleh pegas daun. Hasil dari grafik tersebut sesuai degan hasil grafik fatik pegas daun (gambar 10.b) (SAE Spring Committee, 1996). 
KHOIRUR ROHMAN, RIKA DWI HIDAYATUL QORYAH, ARIS ZAINUL MUTTAQIN, DAN

SANTOSO MULYADI * ANALISIS PENGARUH TEBAL PLAT TERHADAP ...

Tegangan - Siklus

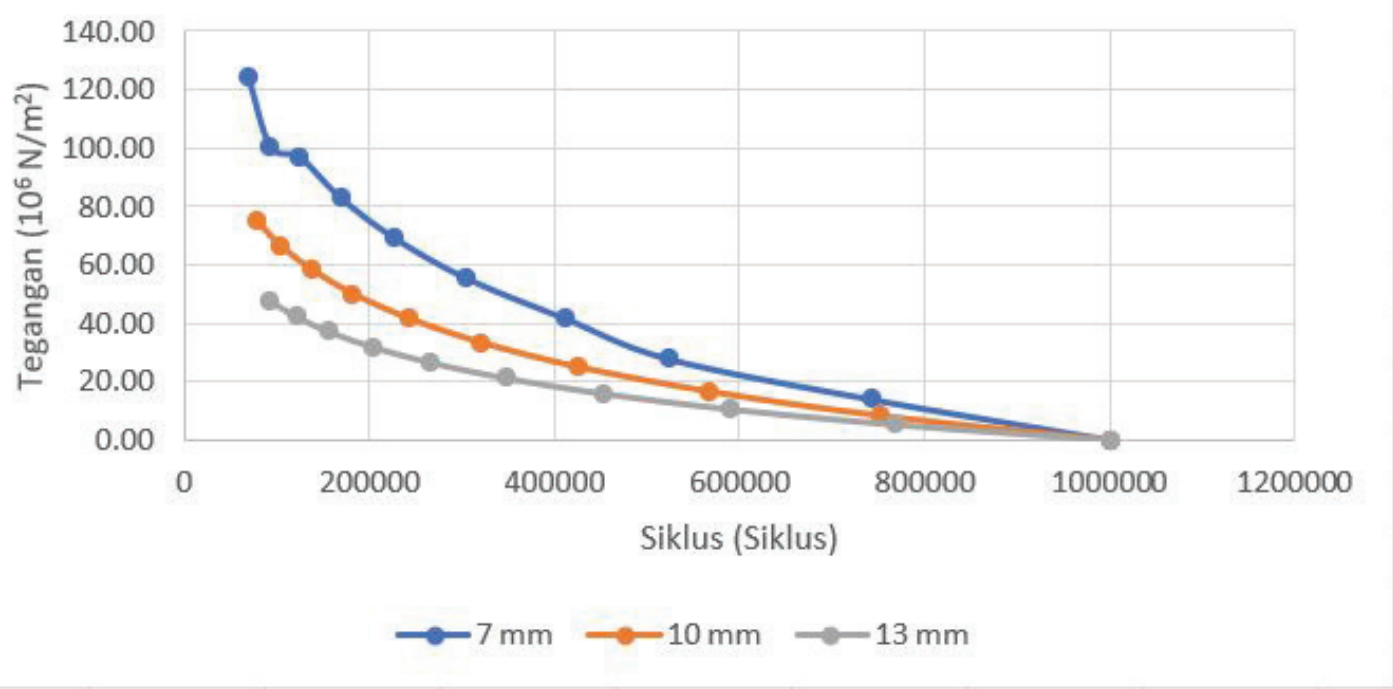

(a)

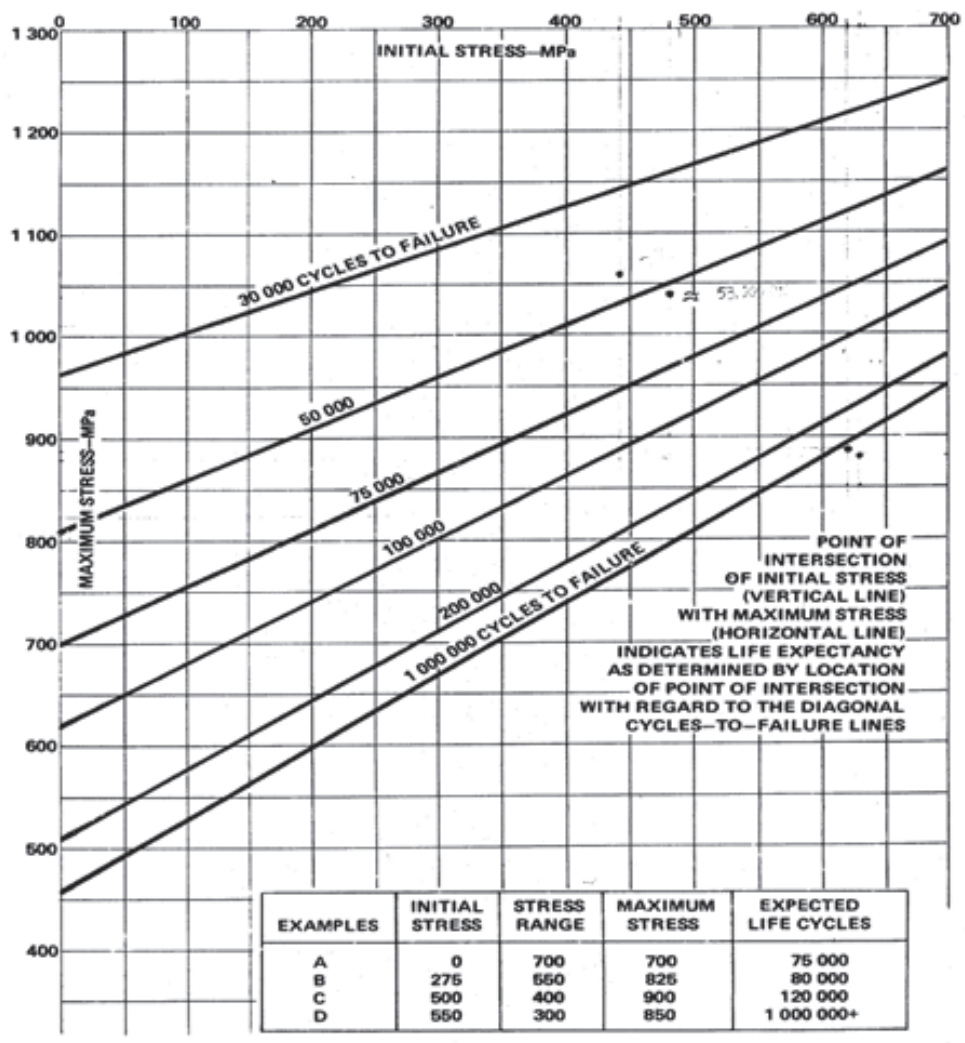

(b)

Gambar 10

Grafik Tegangan-Siklus Pegas Daun 
Tebal pegas daun mempengaruhi life siklus pegas daun. Pertambahan tebal pegas menghasilkan eleman luas penampang pegas daun besar, sehingga nilai tegangan, regangan rendah dan nilai siklus menjadi besar. Dalam pemilihan tebal pegas digunakan parameter siklus pegas, dimana sesuai dengan fungsi pegas sebagai peredam getaran. Getaran merupakan gaya dinamis yang dialami oleh pegas daun dalam satuan waktu tertentu. Semakin besar nilai siklus gaya yang dapat diterima oleh pegas daun maka pegas daun tersebut memiliki masa pakai yang lebih lama.

Berdasarkan tabel 8 pegas daun dengan variasi tebal $13 \mathrm{~mm}$ dapat menerima siklus sebesar 93054 siklus, dari hasil tersebut dapat disimpulkan pegas daun yang paling lama umur pakainya adalah pegas daun dengan tebal $13 \mathrm{~mm}$.

\section{SIMPULAN}

Tebal pegas daun $13 \mathrm{~mm}$ memiliki life siklus tertinggi sebesar 93054 siklus dengan safety factor yaitu 5,72. Hal ini dikarenakan tegangan yang terjadi lebih kecil dibandingkan tebal pegas daun $7 \mathrm{~mm}$ dan $10 \mathrm{~mm}$ dengan nilai $48,08 \times 10^{6} \mathrm{~N} / \mathrm{m}^{2}$, sedangkan regangannya bernilai 0,00029, untuk defleksinya hanya sebesar $0.36 \mathrm{~mm}$. Dari data yang dihasilkan pada penelitian ini, telah memenuhi syarat penggunaan pegas daun pada prototipe mobil Fish Car UNEJ (FCU) MUDSKIP.

Perlu diteliti lebih lanjut dalam pemilihan tebal pegas daun yang paling optimum harus diperhatikan kekuatan fatik, kenyamanan dan meminimalkan bunyi gesekan antar pegas daun, sehingga sesuai dengan fungsi pegas daun sebagai peredam getaran.

\section{DAFTAR PUSTAKA}

AZoM. (2012). AISI 5160 Alloy Steel (UNS G51600). Diakses pada tanggal 12 Januari 2020. Dapat diakses di https://www.azom.com/article. aspx?ArticleID=6743.

Bandarkar, Dhiraj K. and Shekhawat, Sanjay P. (2014). Design, Analysis and Optimization of leaf spring. International Jurnal of Innovative
Research In Science, International Journal of Innovative Research in Science, Engineering And Technology, 6:2319-8753.

Gere, J.M, dan Timoshenko, S.P. (2000). Mechanics of Material. Fourth Edition. PWS Publishing Company. Terjemahan oleh Suryoatmono, Bambang. Mekanika Bahan. Edisi Keempat. Jakarta: Erlangga.

Lukman. (2018). Desain Optimasi Sistem Suspensi pegas Daun Pada Kendaraan Roda 3 Dengan Menggunakan Catia V5, Surakarta: Jurnal Megister Teknik Mesin Universitas Muhammadiyah Surakarta.

Miejaard, J. P. (2015). The Importance Of Imperfections In Leaf Spring Fluxures For The Support Stifnes. IUTM Symposium on "Synamical Analysis of Multibody Systems with Design Uncertanities", 13:82-89.

Sepfitrah dan Rizal, Yose. (2013). Analisis Peristiwa Kegagalan Pada "Leaf Spring" Truk Colt Diesel Pengangkut Pasir. JURNAL APTEK, 5: 2.

Stanco, Mariusz, Iluk, Artur and Dzialak, Paulina. (2018). Numerical and Experimental Analisys of Stress of a Semi Elliptical Spring. DAS, 5: 2676026765.

SAE Spring Committee. (1996). Spring Design Manual. Society of Automotive Engineers, Inc Gunawan, Yuspian dan Sudarsono (2012). Analisis Kekuatan Pegas Daun(Leaf Spring) pada Suzuki Carry Futura 1.5 Mega Cargo. Dinamika Jurnal Ilmiah Teknik Mesin, 3:2.

Thamrin, Ismail. (2009). Analisa TeganganRegangan Struktur Pegas Daun Akibat Modifikasi Penekanan. Jurnal Rekayas Mesin, 9: 1.

Wahyu, Firmansyah A. F. C., Atmawan, Seti, Muthoriq, Ery dan M. K., Herman. (2015). Analisis Kekuatan Suspensi 
KHOIRUR ROHMAN, RIKA DWI HIDAYATUL QORYAH, ARIS ZAINUL MUTTAQIN, DAN

SANTOSO MULYADI \& ANALISIS PENGARUH TEBAL PLAT TERHADAP ...

Pegas Daun Truk Dengan Metode Elemen Hingga. Politeknologi, 14: 3.

Yoga, Ridho, Rohman, Khoirur dan Dwi, Abim. (2018). FCU Mudskip Sebagai
Mobil Desa untuk Transportasi Hasil Perikanan. Jember: Jurusan Teknik Mesin Universitas Jember. 